\title{
THE ROLE OF SPIRITUALITY ON SANTRI COMMUNICATION LEVELS IN ISLAMIC BOARDING SCHOOL OF JAGAD 'ALIMUSSIRRY SURABAYA SURABAYA
}

\author{
D Mutmainah \\ Islamic Boarding School of Jagad 'Alimussirry Surabaya, Indonesia \\ Email: dewimutmainah07@gmail.com
}

\begin{abstract}
This study aims to explain the role of spirituality on the communicative level of students in the Islamic Boarding School Jagad 'Alimussirry Surabaya. The research method used is descriptive qualitative. The study was conducted on all students of the Islamic Boarding School Jagad 'Alimussirry Surabaya and teachers / teachers in a vulnerable period of one semester. Data obtained from questionnaires and observations that have been transcribed, then described in detail according to existing phenomena. The results showed that the role of spirituality on the communicative level of students had a significant influence. Not only for the sake of getting closer to God, but also to improve morals (both to God and His creatures), and to achieve ultimate peace of self and the environment. This is evidenced by the communicative data of students both with fellow students, teachers, and with the natural surroundings.
\end{abstract}

Keywords: role, spirituality, and communicative.

\section{INTRODUCTION}

The communication tool that is considered the most effective is language, rather than gesture, facial expression, symbol, password, or color. Therefore, humans use language as a medium of communication in daily speech activities. As the opinion of Keraf which states that communication is a consequence that is further from selfexpression [9]. Communication will not be perfect if one's self expression is not understood or accepted by others. Humans communicate to convey everything that is felt, thought, and known to others. Communication can also lead the public to learn and inherit everything that has been achieved by the ancestors, as well as what was achieved by the contemporaries. A communication can be said communicative if between the speaker and the interlocutor both understand each other in the speech.
Communication not only has a horizontal nature, where the determination is a mutual understanding relationship between people. However, communication also has a vertical nature which determines the relationship of understanding with God who has created man himself, known as spirituality.

Many people are not too concerned about the benefits of increasing spirituality in perfecting and facilitating communication both communication with God, nature, and with various energies around us, exspecially in this era. The deeds done such as prayer, fasting, alms, etc. are merely to perfect the worship that is required in religious rules, without understanding what effect will be behind these practices and cannot interpret the purpose of the fulfillment efforts. worship performed.

This research is expected to reveal carefully the study of communicability both 
horizontally and vertically, especially when applied in language or speech that occurs among students. It is also hoped that this research will prove that spirituality also has an important role in the level of communication of santri as will be discussed in this study in detail.

In accordance with the background described above, the formulation of the problem in this study is how the role of spirituality in the level of communication between students in the Islamic Boarding School Jagad 'Alimussirry Surabaya.

\section{METHOD}

This research uses a qualitative approach. A qualitative approach in this research that uses observational data to be transcribed later. This research is a descriptive research type. Descriptive type of research is research whose data results are described and explained in detail in accordance with existing phenomena. This descriptive research will produce descriptive data in the form of written data. Descriptive data are then analyzed in such a way and data sorting is carried out as further analysis. The data collected in this study are in the form of students' speeches / conversations and actions resulting from the results of the communicative actions taken. To get natural data, researchers are directly involved in several aspects that require naturality. The data in this study are in the form of utterances and responses / actions that describe the role of santri spirituality in realizing communicativeness.

\section{RESULT AND DISCUSSION}

The role of spirituality towards the level of communicability of students in the Islamic Boarding School Jagad 'Alimussirry is nothing new to hear. The spirituality in this boarding school is not only exemplified or taught through the example of teachers / clerics when teaching, but also spiritual through mentoring or guidance from caregivers in undergoing spiritual stages through practices that are recommended to be done according to the abilities and needs of students. The role of spirituality towards the level of communicability of students can be proven by the actions and communication of students in carrying out daily activities, as follows the following data. The following data is taken from the active female student population of 94 students from 2013-2019.

\section{A. The role of spirituality in the level of communication between queues}

Consider the following data to understand the role of spirituality in the level of communicability between santri and santri.

$$
\begin{array}{ll}
\text { Student A } & \text { : Let's go at dawn. } \\
\text { Student B } & \text { : Yes Mbk (Wake up } \\
& \text { moving bed) }
\end{array}
$$

The data above shows that the understanding captured from the delivery of subject A was not responded well, because the understanding was asked to get up because the previous bed would be used for congregational prayers. Therefore, subject B only moved into bed because he felt sleepy. Thus, the spiritual role does not work well because subject $\mathrm{B}$ is not responsive to what is intended by subject $\mathrm{A}$. It is different from the following data.

$$
\begin{array}{ll}
\text { Student A } & \text { : Let's go at dawn. } \\
\text { Student C } & \text { : Yes Mbk (rushed to } \\
& \text { the bathroom to clean } \\
& \text { themselves and } \\
& \text { ablution) }
\end{array}
$$

In contrast to data (1), data (2) proves that the spiritual embedded in the soul of subject $\mathrm{C}$ is able to provide an understanding of the intentions of subject A. Subject C understands that $\mathrm{He}$ was awakened to join 
the Fajr congregation together. In addition to the two data that illustrate the communication between the queens when they wake up for the Fajr prayer, there are also data that illustrate the communicative relationship between students and teachers as follows.

\section{B. The role of spirituality on the level of communicability between students and teachers.}

Consider the following data to understand the role of spirituality in the level of communicability between students and teachers.

$$
\begin{array}{ll}
\text { Teacher } & : \text { You! (point when } \\
& \text { teaching the Koran) } \\
\text { Student } & : \text { (Reading a book) }
\end{array}
$$

The action taken by the santri showed that he understood what the teacher meant. $\mathrm{He}$ was appointed because he was asked to read the book, therefore He immediately read it. This understanding is based on the understanding of communication done between students and teachers when teaching the Koran in certain books, in connection with the students who have lived in boarding schools. It is different from students who do not understand the meaning of the teacher as the following new students do.

$$
\begin{array}{ll}
\text { Teacher } & \begin{array}{l}
\text { : You! (point when } \\
\text { teaching the Koran) }
\end{array} \\
\text { Student } & : \text { (tolah-toleh) }
\end{array}
$$

The data proves that the actions of the new santri do not understand what the teacher intended as in the data (3). This misunderstanding is based on communication. The point is the usual communication between students and teachers when teaching the Koran in certain books. Both of these data also show that santri laama and santri also have an influence on the communicativeness between santri and teachers / ustadzustadzah.

\section{The role of spirituality on the level of communicability between students and the natural surroundings.}

Other data shown aside from fellow humans is also with the universe. Consider the following data.

$$
\begin{array}{ll}
\text { Garden } & : \text { (lush) } \\
\text { Student } & : \text { (cutting and cleaning } \\
& \text { plants) }
\end{array}
$$

The action taken by the santri in the data shows that the santri is responsive to the natural surroundings. The santri are responsive to the communication delivered by the 'park', which in this case conveys that the park needs to be cared for and tidied up. Different from the following data.

$$
\begin{array}{ll}
\text { Garden } & : \text { (lush) } \\
\text { Student } & : \text { (indifferent) }
\end{array}
$$

Understanding that was not conveyed as the data shows that the intention of the park's desire to be cared for and tidied up was not well conveyed. Regarding spiritual communication, this action shows that the degree of communicative is not going well. That is because it is proven by the insensitivity of the santri to the natural surroundings, even though the natural environment also benefits us all, especially helping us breathe oxygen. In addition, the park also helps so that the place we live in does not experience drought or arid.

\section{The role of spirituality towards the level of communicability between students and God.}

The most important communicative is the level of communicative to God. When communication with God goes well, then 
everything done by individuals will be easier and create a sense of peace. Consider the following data that interpret the communicative nature of the practices carried out by students.

$$
\text { Student } \quad \begin{aligned}
& \text { (fasting with the } \\
& \text { guidance of } \\
& \text { caretakers of the } \\
& \text { cottage) }
\end{aligned}
$$

The practice of fasting students shows that it is done as an effort to get closer to Allah. However, the practice of fasting does not all bring spiritual communication to students. There are some students who can interpret the benefits of fasting, there are those who can not interpret it so that fasting is only a day-long hunger.

a) Communicative students with the practice carried out

Communicative students in their spiritual practice are students who can interpret the meaning behind the fasting done. Every thing that is done while doing the fasting practice is able to be interpreted properly. The interpretation is proven, among others, withholding hunger which is interpreted by helping the digestive work in the body, withholding the desire not to do something that is forbidden by religion, and being patient when overheating or thirsting. The santri are responsive and sensitive to what is conveyed by the practice they run. Not to show off because they are able to do penance or practices that aim to purify the soul.

b) Santri who are not communicative with the practice being carried out

Santri who are not communicative with their practices can be interpreted as santri who are less responsive and sensitive to what they are doing. This Santri does not try to understand what the benefits of the deeds are made, he merely fasts to abort obligations, for example when fasting Ramadan. Everything experienced when fasting is ignored without consideration.
Enduring hunger and thirst to wait for the coming of breaking the fast. It also applies the same as other practices, such as wiridan, pilgrimage trustees in a certain period of time, and excetra.

\section{CONCLUSION}

The role of spirituality on the level of communicability of students in Jagad Islamic Boarding School 'Alimussirry is very important because it can influence the activities and practices carried out by students, both vertically and horizontally.

The role of spirituality towards the level of communicability of students in the Islamic Boarding School Jagad 'Alimussirry Surabaya can be proven by the actions of students who are sensitive to others and the surrounding environment. Sensitive to improve and evaluate the meanings of all things experienced in daily activities.

Spirituality has a role in increasing the communicativeness of santri in Jagad 'Alimussirry Islamic Boarding School in terms of business. The more effort done, the better the reciprocity that gets, even though in practice it does not expect compensation.

\section{REFERENCES}

[1] B. Bara G. "Cognitive pragmatics :The Mental Processes of Communication / Bruno G. Bara; translated by John Douthwaite". United States of Amerika: MIT Press. 2010.

[2] CJ. Weir. "Communicative Language Testing". New York: Prentice Hall. 1990.

[3] G. Yule. "Pragmatik". Yogyakarta: Pustaka Pelajar. 2006.

[4] H. B. Abintara. "Pengaruh Spiritualitas terhadap Kebahagiaan 
melalui Kebermaknaan Hidup pada

Tentara Nasional Indonesia

BINTALDAM V/Brawijawa. 2015. (Accessed on $28^{\text {th }}$ December 2018). etheses.uin malang.ac.id/1523/11/11410082_Rin gkasan.pdf

[5] H. Douglas Brown. "Teaching by Principles: An Interactive Approach to Language Pedagogy". San Francisco: Longman, 2001.

[6] J.C. Richards. Communicative Language Teaching Today. New York: Cambridge University Press.

[7] JWM. Verhaar, "Asas-asas Linguistik”. Yogyakarta: Gajah Mada University Press., 2001.

[8] Sudaryanto. "Metode dan Aneka Teknik Analisis Bahasa: Pengantar Penelitian Wahana Kebudayaan secara Linguistik”. Yogyakarta: Duta Wacana University Press. 1993.

[9] G. Keraf.. Komposisi. Jakarta: Nusa Indah, 1980.

[10] G. Leech. Prinsip-prinsip Pragmatik. Jakarta: Universitas Indonesia Press., 1993.

[11] P. Nandaka. "Spiritualitas: Makna dan Fungsi" 2018. (Accessed on $28^{\text {th }}$ December 2018). http://buletin.kpin.org/index.php/arsip-artikel/244spiritualitas-makna-dan-fungsi.

[12] T. M. J. Kesuma. Pengantar (Metode) Penelitian Bahasa. Yogyakarta: Carasvatibooks, 2007.

[13] T. Suwartono. "Kekomunikatifan Penggunaan Bahasa Dalam Pembelajaran Bahasa Indonesia di SMP Negeri di Kecamatan Purwokerto Selatan". 2016. (Accessed on $28^{\text {th }}$ December 2018). https://www.researchgate.net/.../3209 44574_Kekomunikatifan_Penggunaa n_Bahasa. 